\title{
COMPOSITIONAL EFFECTS ON ALUMINIDE OXIDATION PERFORMANCE: OBJECTIVES FOR IMPROVED BOND COATS
}

\author{
B. A. Pint, J. A. Haynes, K. L. More, I. G. Wright and C. Leyens* \\ Oak Ridge National Laboratory \\ Metals and Ceramics Division \\ Oak Ridge, TN 37831-6156 \\ * on leave from DLR - German Aerospace Center \\ Institute of Materials Research \\ 51170 Cologne, Germany
}

\begin{abstract}
In order to achieve long thermal barrier coating lifetimes, underlying metallic bond coats need to form adherent, slowgrowing $\mathrm{Al}_{2} \mathrm{O}_{3}$ layers. A set of guidelines for developing aluminide bond coat compositions is proposed in order to maximize oxidation performance, i.e. forming a slow-growing adherent alumina scale. These criteria are based on results from cast, model alloy compositions and coatings made in a laboratoryscale chemical vapor deposition facility. Aluminide coatings are thought to have more long-range potential because of their lower coefficient of thermal expansion compared to MCrAlYs. The role
\end{abstract}

of Pt in improving alumina scale adhesion and countering the detrimental role of indigenous sulfur is discussed. However, the improvements associated with $\mathrm{Pt}$ are minimal compared to reactive element doping. One strategy which has great promise for improvement is to incorporate Hf into the coating. From an oxidation standpoint, this would preclude the need for $\mathrm{Pt}$ in the coating and also reduce the scale growth rate. While excellent oxidation performance was observed for cast Hf-doped $\mathrm{NiAl}$, its benefits can be compromised and even eliminated by co-doping with elements such as $\mathrm{Cr}, \mathrm{Ti}, \mathrm{Ta}$ and $\mathrm{Re}$. Creating a pure Hf-doped $\mathrm{NiAl}$ is one promising approach for improving the oxidation performance of bond coats. 


\section{Introduction}

Formerly, the role of metallic coatings on Ni-base superalloys was simply to limit environmental attack of the underlying substrate. Now, a new paradigm has been established for metallic coatings that have been adapted as bond coats for thermal barrier coating (TBC) systems. It is no longer sufficient that the metallic coating simply minimize the corrosion rate. The metallic coating must form an adherent, slow-growing external $\mathrm{Al}_{2} \mathrm{O}_{3}$ layer beneath the overlying low thermal conductivity ceramic top coat. The ability of the coating to reform a protective thermally grown oxide or scale in the event of spallation is no longer the key. It is much more important that the scale be developed with a minimum of transient oxides and that it have near-perfect adhesion to limit spallation of the ceramic top coat, thereby achieving a long TBC lifetime.

While oxidation is not the only concern in complex TBC systems, it is, however, a primary factor in developing the next generation of bond coats with longer lifetimes or for engines with higher firing temperatures. Therefore, a set of compositional guidelines for coatings is proposed in order to assist in maximizing oxidation performance. These criteria are based on results from tests in which cast alloy compositions were used to quantify and understand possible improvements as a basis for further investigations using coatings made by chemical vapor deposition (CVD). Experimental work involved furnace cycle testing, isothermal kinetic measurements and in-depth characterization of the alumina scale, including transmission electron microscopy (TEM).

\section{Experimental Procedure}

Cast alloys (16mm diameter) were fabricated by vacuum induction melting and solidifying in a water-chilled copper mold. Chemical compositions were measured by inductively coupled plasma analysis and combustion analysis on as-cast material, Table I. All compositions are listed in atomic percent. After casting, alloys were annealed for $4 \mathrm{~h}$ at $1300^{\circ} \mathrm{C}$ in quartz ampules. Oxidation coupons (1-1.5mm thick, typically $15 \mathrm{~mm}$ diameter) were polished to $0.3 \mu \mathrm{m}$ alumina and cleaned in acetone and methanol prior to oxidation. Aluminide coatings with and without Pt were fabricated by a CVD process on Y-free, René N5 substrates (a General
Electric single crystal superalloy). This low-sulfur coating process is described in detail elsewhere. $[1,2]$

Isothermal exposures were performed in dry, flowing $\mathrm{O}_{2}$ and mass gain was measured using a Cahn Instruments model 1000 microbalance. Cyclic testing was performed in two ways.[3] Long-term cycles (100-500h) were conducted in air with specimens in individual pre-annealed alumina crucibles. Crucibles and specimens were cooled to room temperature for $>1 \mathrm{~h}$ before weighing. Short-term (1-10h) cycles were performed in dry, flowing oxygen with specimens attached to alumina rods with Pt$\mathrm{Rh}$ wires. Specimens were cooled for $10 \mathrm{~min}$ between cycles and the cycle time is the time at temperature. Specimen mass changes were measured using a Mettler model AG245 balance. Hot corrosion testing was performed at $950^{\circ} \mathrm{C}$ and used $1 \mathrm{~h}$ thermal cycles. Specimens were coated with $1.0 \mathrm{mg} / \mathrm{cm}^{2} \mathrm{Na}_{2} \mathrm{SO}_{4}$ after $1 \mathrm{~h}$ and $100 \mathrm{~h}$. This testing is described in detail elsewhere.[4]

After oxidation, specimens were characterized by field emission gun, scanning electron microscopy (FEG-SEM) equipped with energy dispersive $\mathrm{X}$-ray analysis (EDX). Specimens also were $\mathrm{Cu}-$ coated and sectioned for metallography. Scanning transmission electron microscopy (FEG-STEM) equipped with EDX was used to analyze cross-sectional specimens fabricated by focused ion beam milling (FIB).[5] During FIB specimen preparation, a W layer is deposited to protect the gas interface of the scale. Thermal expansion measurements were performed on specimens $(3 \mathrm{~mm}$ diameter, $1 \mathrm{~cm}$ or $2.5 \mathrm{~cm}$ long) of several alloys up to $1200^{\circ} \mathrm{C}$ on a Theta Industries dual push rod differential dilatometer.

\section{$\underline{\text { Results }}$}

These results focus on nickel aluminide compositions. While MCrAlY-based coatings represent an important class of coatings for current applications, results from this lab suggest that scale adhesion on MCrAlYs is inherently inferior to that on aluminides at $1100^{\circ}-1200^{\circ} \mathrm{C}[6,7]$ and therefore this coating approach does not represent the most fruitful option for developing high temperature bond coats. Figure 1 compares the temperature dependence of the coefficient of thermal expansion (CTE) of René N5 (Table I) and castings of generic bond coat compositions: $\mathrm{NiAl}+\mathrm{Hf}$ and NiCoCrAlY. While the CTEs for René N5 and NiAl+Hf are reasonably similar, that for NiCoCrAlY was found to be significantly greater at temperatures above $600^{\circ} \mathrm{C}$. These results

\begin{tabular}{|c|c|c|c|c|c|c|c|c|}
\hline & $\mathrm{Ni}$ & $\mathrm{Al}$ & Hf & $\mathrm{Pt}$ & $\mathrm{Cr}$ & $\mathrm{C}$ & S(ppma) & Other \\
\hline $\mathrm{Ni}-40 \mathrm{Al}$ & 59.68 & 40.27 & $<0.01$ & - & $<0.01$ & 0.04 & $<4$ & \\
\hline $\mathrm{Ni}-42.5 \mathrm{Al}$ & 57.34 & 42.61 & $<0.01$ & -- & $<0.01$ & 0.04 & $<4$ & \\
\hline $\mathrm{Ni}-50 \mathrm{Al}$ & 49.91 & 50.05 & $<0.01$ & - & $<0.01$ & 0.04 & $<4$ & \\
\hline $\mathrm{Ni}-51 \mathrm{Al}$ & 48.67 & 51.22 & $<0.01$ & - & $<0.01$ & 0.04 & 4 & $0.01 \mathrm{Fe}, 0.06 \mathrm{Si}$ \\
\hline $\mathrm{Ni}-40 \mathrm{Al}+\mathrm{Hf}$ & 59.79 & 40.11 & 0.05 & $<0.01$ & $<0.01$ & 0.04 & $<4$ & \\
\hline $\mathrm{Ni}-42.5 \mathrm{Al}+\mathrm{Hf}$ & 58.00 & 41.90 & 0.05 & $<0.01$ & $<0.01$ & 0.04 & $<4$ & \\
\hline $\mathrm{Ni}-50 \mathrm{Al}+\mathrm{Hf}$ & 49.83 & 50.07 & 0.05 & - & 0.01 & 0.04 & $<4$ & \\
\hline $\mathrm{NiAl}-2 \mathrm{Pt}$ & 47.36 & 50.21 & 0.005 & 2.35 & $<0.01$ & 0.04 & 4 & $0.01 \mathrm{Fe}, 0.01 \mathrm{Cu}$ \\
\hline NiAl-5Pt & 45.10 & 49.60 & $<0.01$ & 5.20 & 0.05 & 0.04 & 9 & \\
\hline $\mathrm{NiAl}-2 \mathrm{Pt}+\mathrm{Hf}$ & 47.78 & 49.71 & 0.05 & 2.35 & 0.03 & 0.04 & 4 & $0.01 \mathrm{Cu}$ \\
\hline $\mathrm{NiAl}-2 \mathrm{Cr}+\mathrm{Hf}$ & 48.28 & 49.63 & 0.05 & $<0.01$ & 2.00 & 0.04 & 4 & \\
\hline $\mathrm{NiAl}-5 \mathrm{Cr}+\mathrm{Hf}$ & 47.76 & 47.20 & 0.05 & $<0.01$ & 4.95 & 0.04 & 8 & \\
\hline $\mathrm{NiAl}-10 \mathrm{Cr}+\mathrm{Hf}$ & 45.13 & 45.07 & 0.05 & $<0.01$ & 9.70 & 0.04 & 5 & $0.01 \mathrm{Fe}$ \\
\hline $\mathrm{NiAl}-1 \mathrm{Re}+\mathrm{Hf}$ & 48.37 & 50.53 & 0.04 & - & $<0.01$ & 0.04 & 1 & $1.00 \mathrm{Re}, 0.02 \mathrm{Si}$ \\
\hline $\mathrm{NiAl}-1 \mathrm{Ta}+\mathrm{Hf}$ & 48.67 & 50.15 & 0.05 & - & $<0.01$ & 0.04 & 4 & $0.92 \mathrm{Ta}, 0.14 \mathrm{Fe}, 0.01 \mathrm{Co}$ \\
\hline $\mathrm{NiAl}-1 \mathrm{Ti}+\mathrm{Hf}$ & 48.58 & 50.33 & 0.05 & -- & $<0.01$ & 0.04 & 1 & $1.00 \mathrm{Ti}, 0.01 \mathrm{Fe}$ \\
\hline René N5 & 64.85 & 13.88 & 0.05 & -- & 7.79 & 0.25 & 7 & 2.1Ta,7.3Co,1.6W,1.0Re,.01Y \\
\hline NiCoCrAlY & 40.38 & 23.49 & $<0.01$ & -- & 17.43 & 0.04 & 8 & $18.48 \mathrm{Co}, 0.15 \mathrm{Y}, 0.01 \mathrm{Ti}$ \\
\hline
\end{tabular}




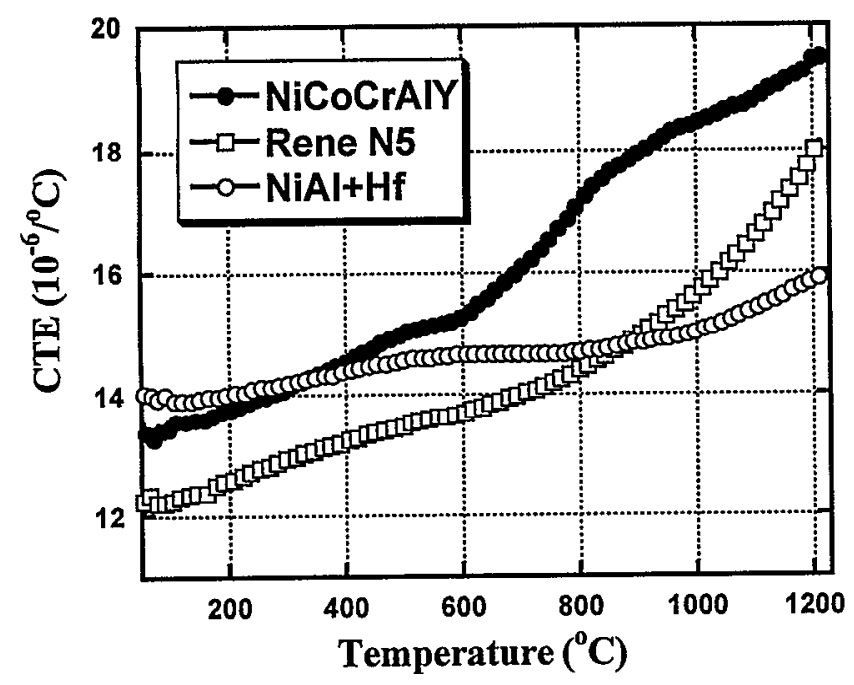

Figure 1. Coefficient of thermal expansion data for 3 alloys from $25^{\circ}-1200^{\circ} \mathrm{C}$. The aluminide specimen had the lowest expansion from $900^{\circ}-1200^{\circ} \mathrm{C}$.

are similar to earlier work. [8] Since the thermal stress in the alumina scale is related to the CTE difference, the additional thermal expansion compared to that for alumina $\left(\approx 9 \times 10^{-6} \mathrm{C}^{-1}\right)$ represents a significant increase in thermal stress. Such a problem cannot be solved by reactive element (RE) doping or impurity control (e.g. S) and thus is an inherent limitation of the MCrAlY class of materials. Therefore, this work attempts have been made to understand and optimize the oxidation performance of aluminide coatings.

\section{Current Compositions: The Pt Effect}

Current aluminide bond coats often contain $\mathrm{Pt}$, which is now commonly added in conjunction with a low activity CVD aluminization process which results in a single phase $\beta-(\mathrm{Ni}, \mathrm{Pt}) \mathrm{Al}$ coating.[9] The role of $\mathrm{Pt}$ in oxidation has not been fully explained but it is clear from recent results on both cast aluminides [10] and CVD aluminide coatings [2] that Pt improves alumina scale adhesion. This beneficial effect is shown at $1100^{\circ} \mathrm{C}$ for cast aluminides, Figure 2 . With the addition of 2 or $5 \mathrm{at} \% \mathrm{Pt}$ (10 or $20 \mathrm{wt} \%$ ), very little scale spallation was observed after 1000 cycles. Under the same conditions, undoped $\mathrm{NiAl}$ showed significant scale spallation. When Pt was added to CVD aluminide coatings, $\mathrm{Pt}$ mitigated the detrimental role of sulfur, present in the superalloy (Y-free René N5) substrate, on scale adhesion, Figure 3. Previous work on CVD NiAl coatings (without $\mathrm{Pt}$ ) had shown that substrate sulfur content had a significant effect on alumina scale adhesion.[1] This result suggests that $P$ t somehow counters the detrimental role of $S$. One suggested mechanism for the effect of $\mathrm{S}$ on scale adhesion is that it increases the growth of interfacial voids. $[11,12]$ The addition of $\mathrm{Pt}$ to CVD NiAl appeared to have reduced or eliminated this type of void growth, thereby improving contact between the metal and scale.[13]

The comparison of simple and Pt-modified CVD aluminide coatings on René N5 aiso demonstrated that $\mathrm{Pt}$ did not (1) reduce the alumina scale growth rate, (2) alter the diffusion of heavy elements into the coating during deposition or oxidation, or (3) alter the coating Al content before or after oxidation.[2,13].

Another area where the addition of $\mathrm{Pt}$ did not appear to play a strong role was hot corrosion resistance.[14] Figure 4 shows

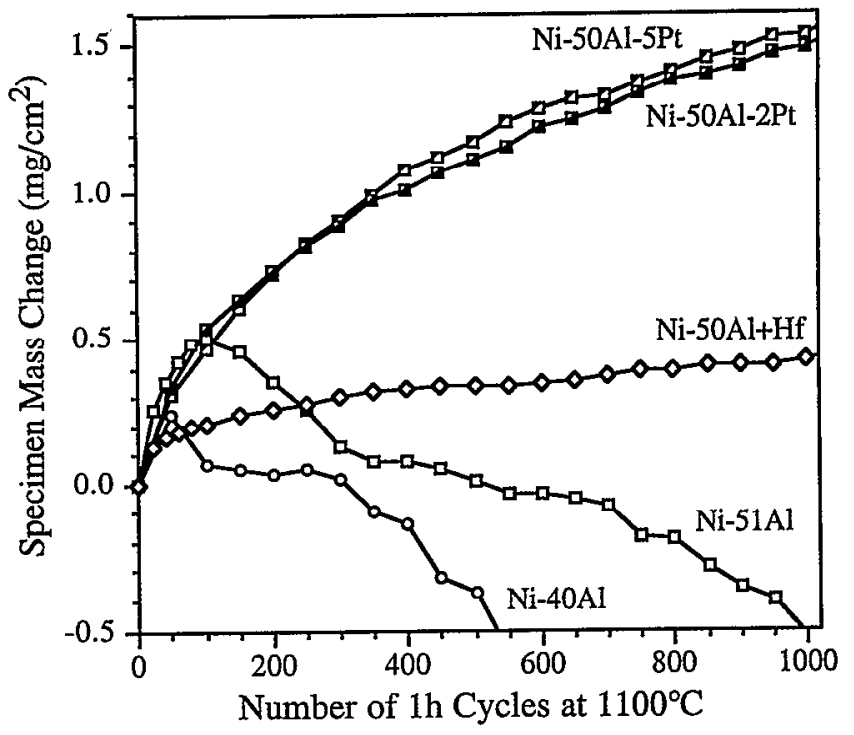

Figure 2. Specimen mass changes for various Ni-Al alloys during 1 h cycles at $1100^{\circ} \mathrm{C}$ in $\mathrm{O}_{2}$. The addition of $\mathrm{Pt}$ significantly improved scale adhesion compared to simple aluminides without Hf. The addition of $\mathrm{Hf}$ improved scale adhesion and reduced the scale growth rate.

results from testing at $950^{\circ} \mathrm{C}$ with a $1.0 \mathrm{mg} / \mathrm{cm}^{2} \mathrm{Na}_{2} \mathrm{SO}_{4}$ coating applied after $1 \mathrm{~h}$ and $100 \mathrm{~h}$. Additions of $\mathrm{Pt}$ did not alter the behavior compared to $\mathrm{NiAl}+\mathrm{Hf}$. Only the addition of $\mathrm{Cr}$ improved performance. While Pt-modified aluminide coatings may be superior to simple aluminide coatings in hot corrosion due to a second order effect of improved alumina scale adhesion, there is no chemical effect of $\mathrm{Pt}$ in improving hot corrosion resistance. The $\mathrm{Cr}$ content of the coating is the critical component.

To provide additional information on the role of $\mathrm{Pt}$ on scale adhesion, TEM cross-sections were prepared of the scale formed on NiAl-5Pt after $2 \mathrm{~h}$ at $1200^{\circ} \mathrm{C}$ in $\mathrm{O}_{2}$. These conditions were selected to develop a $1-2 \mu \mathrm{m}$ thick oxide layer which is fully $\alpha$ phase and to allow comparison with previous work. In general the scale was $1-1.5 \mu \mathrm{m}$ thick and no transient $\mathrm{Ni}$-rich oxidc was observed. As surmised from the good scale adhesion, there were no interfacial voids observed in the thin area, Figure 5 . The scale

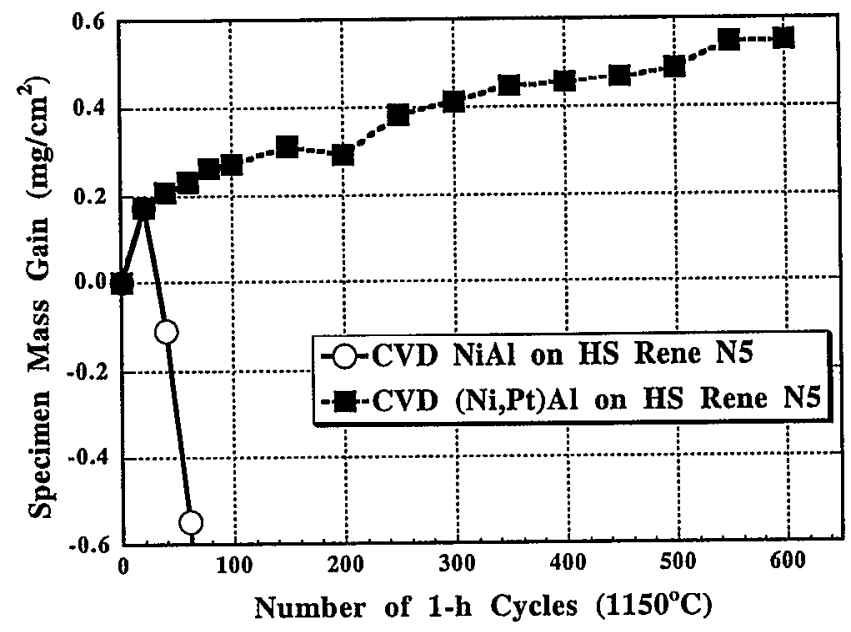

Figure 3. Specimen mass changes during $1 \mathrm{~h}$ cycles at $1150^{\circ} \mathrm{C}$ for CVD aluminide coatings with and without $P t$ on a Y-free René N5 substrate that was not de-sulfurized (4 ppma S). 


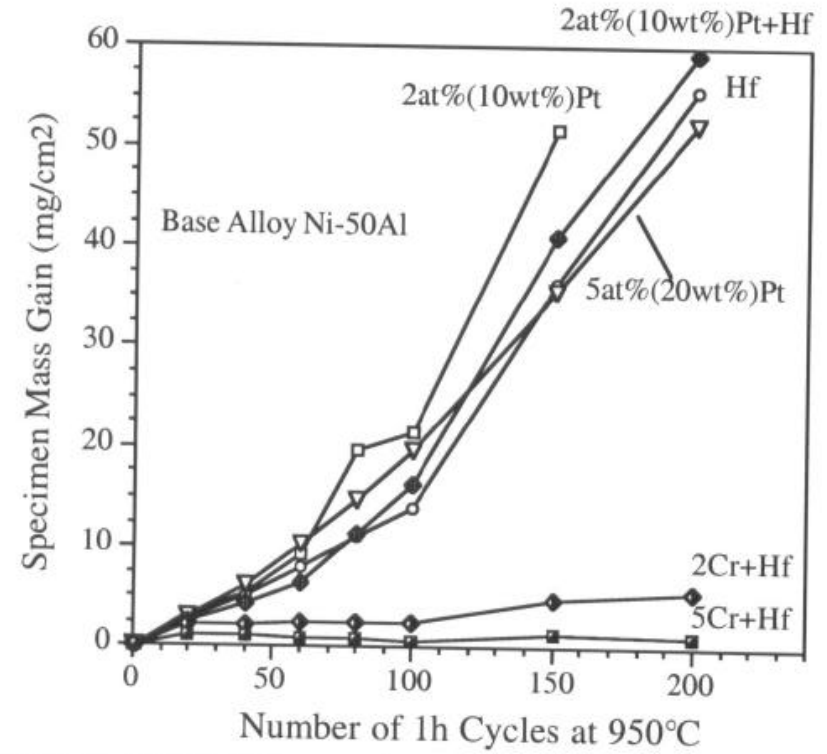

Figure 4. Hot corrosion specimen mass gains at $950^{\circ} \mathrm{C}$ for cast $\mathrm{NiAl}$ alloys with various modifications. All specimens were coated with $1.0 \mathrm{mg} / \mathrm{cm}^{2} \mathrm{Na}_{2} \mathrm{SO}_{4}$ after $\mathrm{lh}$ and $100 \mathrm{~h}$. Chromium had a beneficial effect but $\mathrm{Pt}$ and $\mathrm{Hf}$ showed no benefit.

was generally two grains thick with the outer grains containing more voids than the inner, more columnar grains.

The most interesting feature of the scale was the roughness of the metal-scale interface, particularly the metal protrusions extending into the oxide. Protrusions have been observed previously for both cast Pt-Al alloys [15] and for CVD Pt aluminide coatings. [2] Each protrusion was centered on a single alumina grain and extended into it. This is seen clearly in a STEM annular dark field image, Figure 6. As transport occurs primarily along alumina grain boundaries at this temperature, one explanation for the formation of these protrusions is that new oxide is forming rapidly at the

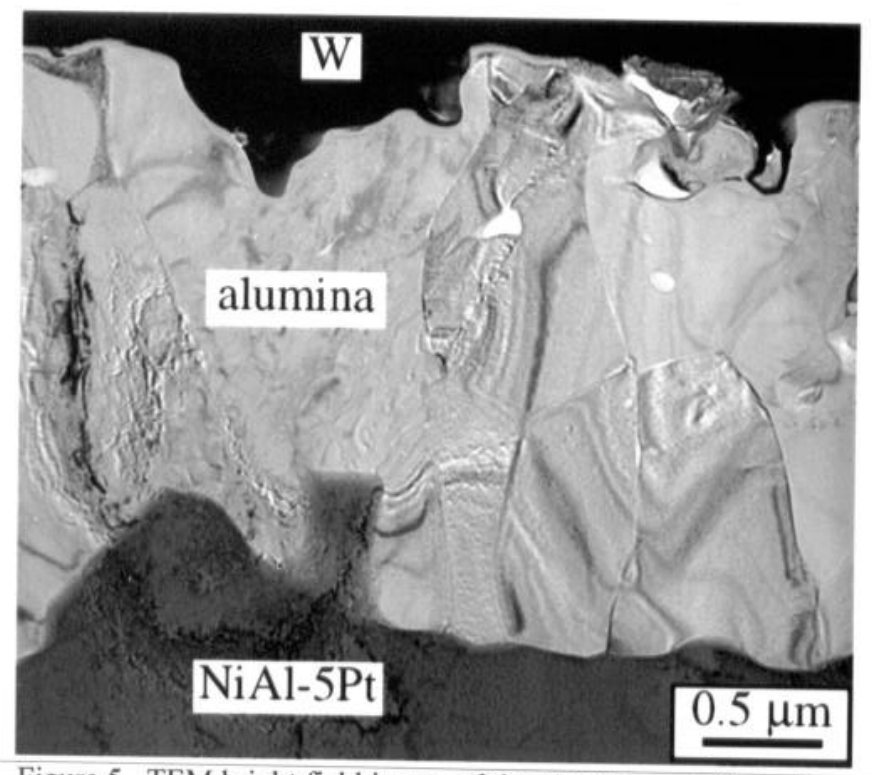

Figure 5. TEM bright field image of the alumina scale formed on $\mathrm{NiAl}-5 \mathrm{Pt}$ after $2 \mathrm{~h}$ at $1200^{\circ} \mathrm{C}$. In general, the scale is two grains thick and neither the gas interface or metal interface of the scale is smooth. The W coating is part of the FIB specimen preparation.

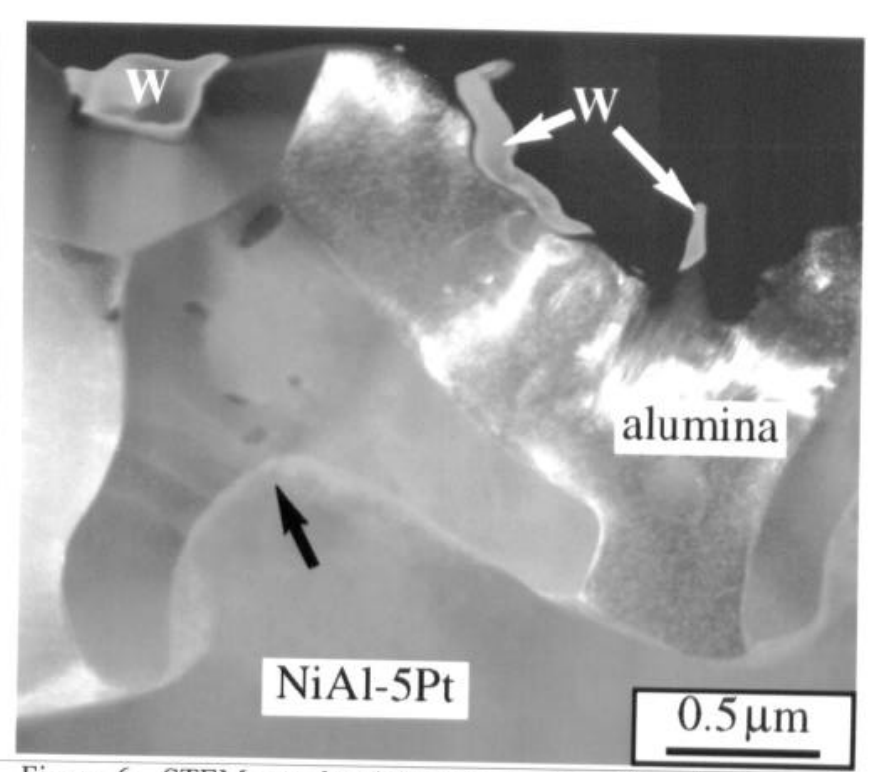

Figure 6. STEM annular dark field image of the alumina scale formed on NiAl-5Pt after $2 \mathrm{~h}$ at $1200^{\circ} \mathrm{C}$. Above the metal protrusion (arrow) is a single alumina grain. Small remnants of the FIB-process $\mathrm{W}$ coating remain at the gas interface of the scale.

juncture of oxide grain boundaries and the metal. If lateral oxygen diffusion does not keep up with this process, the interface will not remain flat. Inward growing ridges have been observed on undoped $\mathrm{NiAl}[16]$ and when the oxide loses contact with the metal due to interfacial void formation.[12] The ridges have been proposed to grow by a similar mechanism where lateral diffusion cannot keep up with the inward grain boundary diffusion of oxygen.[12] In this case where no voids form, the ridges appear to grow into the substrate leaving metal protruding into the center of the oxide grain. While the structure looks like the metal grew into the oxide, it may actually be metal remaining from a non-uniform oxidation front. The gas interface of the scale also was rough. This

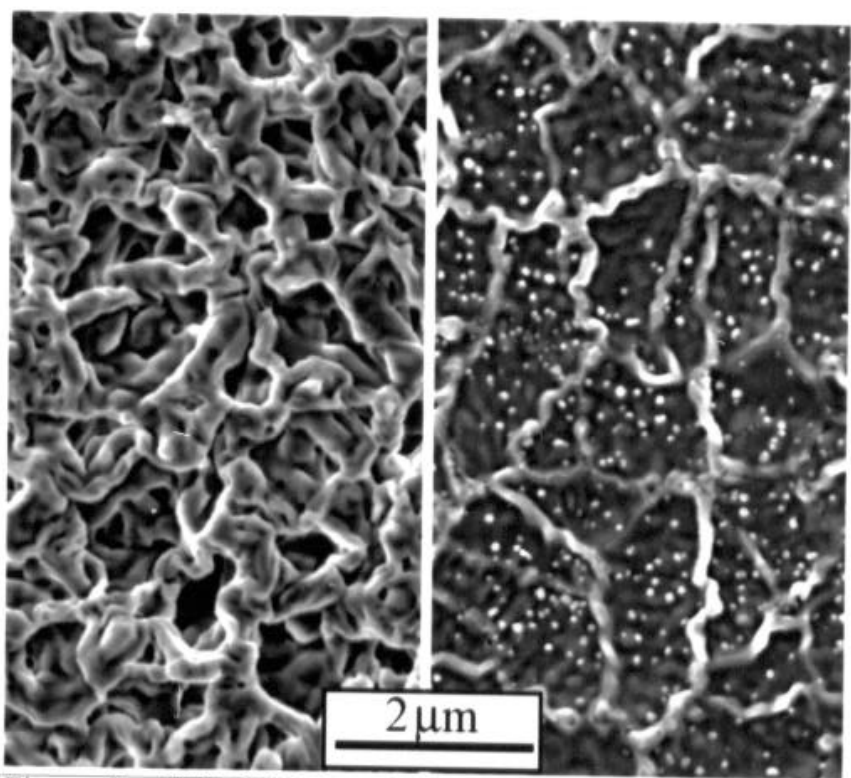

Figure 7. FEG-SEM plan-view images of the alumina scale formed after $2 \mathrm{~h}$ at $1200^{\circ} \mathrm{C}$ on (a) NiAl-5Pt and (b) NiAl-2Pt+Hf. The "intrinsic" ridges in (a) are much wider and form due to outward Al transport. The "extrinsic" ridges in (b) remain from the $\theta-\alpha$ phase transformation. 
is typical of undoped alumina scales (those formed on substrates without a RE dopant) which form a network of closely spaced "intrinsic" ridges (Figure 7a) at this temperature due to the outward diffusion of Al.[17,18] Thus, the adherent alumina scales on (Ni,Pt)Al are attributed to the elimination of voids at the metalscale interface and the metal protrusions into the scale acting as a mechanical interlock.

\section{Ideal Alumina-Formation: The Hf Effect}

While $\mathrm{Pt}$ is beneficial to alumina-scale adhesion, its overall influence on oxidation behavior is minimal compared to that of an optimized RE addition, particularly $0.05 \% \mathrm{Hf}$.[10] (Yttrium is not considered a viable alternative to $\mathrm{Hf}$ for aluminides because it readily forms $\mathrm{NiY}_{\mathrm{x}}$ precipitates, which internally oxidize and disrupt scale formation.[19]) Hafnium not only improves alumina scale adhesion but also has been shown to reduce the scale growth rate by an order of magnitude compared to undoped $\beta-\mathrm{NiAl}$ $[10,20]$. This effect is evident in Figures 2 and 8 when comparing the cyclic oxidation behavior of Pt-doped $\mathrm{NiAl}$ to $\mathrm{Hf}$-doped NiAl. Both alloys form adherent alumina scales at $1100^{\circ} \mathrm{C}$ but, because the scale on $\mathrm{NiAl}+\mathrm{Hf}$ grows more slowly, it has a significant longterm advantage. There is some critical scale thickness where the thermal cooling strains will exceed the interfacial strength and scale spallation cannot be avoided. Empirical models have suggested critical scale thicknesses in the $10-15 \mu \mathrm{m}$ range (corresponding to $\approx 2-3 \mathrm{mg} / \mathrm{cm}^{2}$ ), e.g. Ref.21. After $1000 \mathrm{~h}$ at $1100^{\circ} \mathrm{C}$, this level has not been reached. However, at $1150^{\circ} \mathrm{C}$, this limit is attained for Pt-doped $\mathrm{NiAl}$ and spallation was observed to occur after less than $1000,1 \mathrm{~h}$ cycles, Figure 8 . With the slower growing scale on Hf-doped $\mathrm{NiAl}$, the critical scale thickness will not be reached for thousands of hours. No additional benefit was observed from combining Pt- and Hf-doping, Figure 8.

The scale microstructure formed on $\mathrm{Hf}$-doped $\mathrm{NiAl}$ was investigated by TEM. On this substrate, the scale was thinner and had fewer internal voids than that formed on NiAl-5Pt (compare Figures 5 and 9). The addition of $\mathrm{Hf}$ is believed to act like $\mathrm{Zr}$ and inhibit the outward $\mathrm{Al}$ boundary transport,[17] resulting in growth

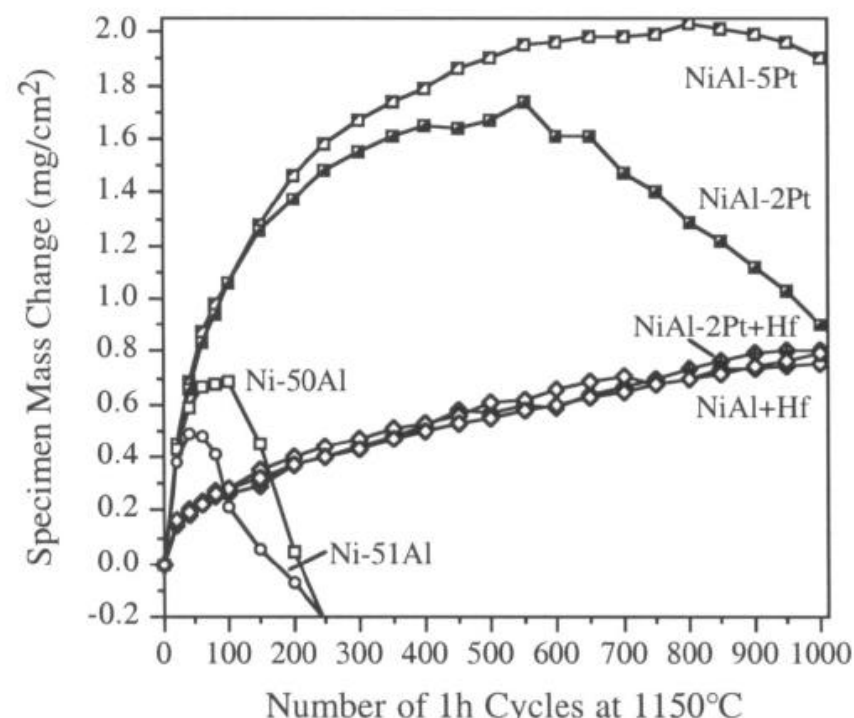

Figure 8. Specimen mass changes for various $\mathrm{Ni}-\mathrm{Al}$ alloys during Ih cycles at $1150^{\circ} \mathrm{C}$ in $\mathrm{O}_{2}$. The addition of $\mathrm{Pt}$ significantly improved scale adhesion compared to simple aluminides without Hf. The addition of $\mathrm{Hf}$ improved scale adhesion and reduced the scale growth rate.

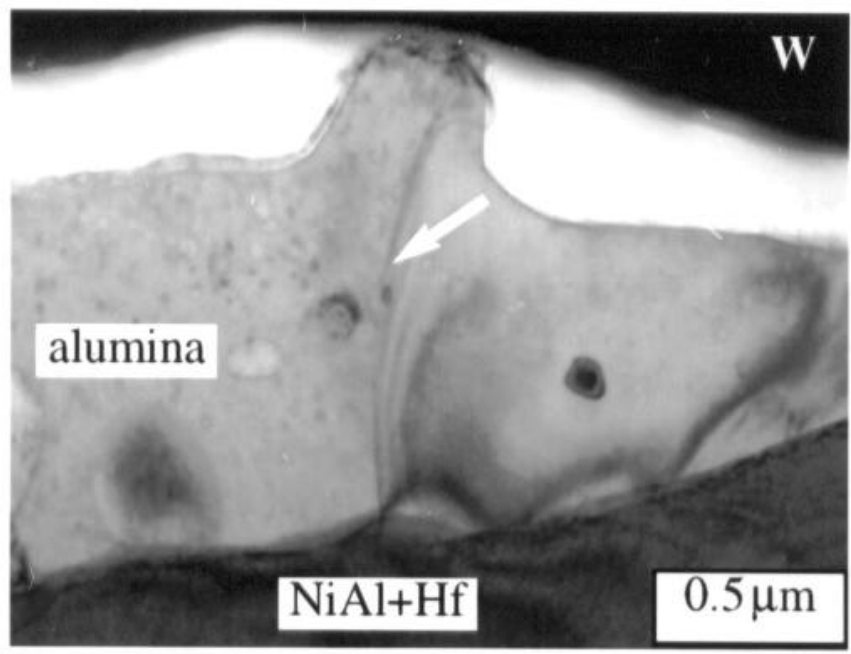

Figure 9. TEM bright field image of the alumina scale formed on $\mathrm{NiAl}+\mathrm{Hf}$ after $2 \mathrm{~h}$ at $1200^{\circ} \mathrm{C}$. Grain boundaries (arrow) are associated with the ridges at the gas interface and the scale is only one grain thick. The W coating was part of the FIB preparation.

primarily by inward grain boundary diffusion of oxygen. This eliminates the intrinsic ridges and leaves only the "extrinsic" ridges $[18,22]$ from the $\theta-\alpha$ phase transformation, Figure $7 \mathrm{~b}$. At each of the extrinsic ridges, a grain boundary was observed as predicted.[22] Using STEM/EDX, Hf ions were detected as segregants to the scale grain boundaries and the metal-scale interface. Similar behavior has been observed for all RE additions. [7,10,17,23-30] The segregation of Hf ions is the most likely explanation for the low scale growth rate; however, its benefit over other dopants (e.g. Y and $\mathrm{Zr}$ ), which also segregate at similar levels, has not been explained.

Thus, a promising approach to improved coating performance would be to incorporate $\mathrm{Hf}$ at the appropriate level in an aluminide coating, thereby achieving a significant improvement in alumina scale adhesion and making the addition of Pt unnecessary, at least from the viewpoint of oxidation behavior.

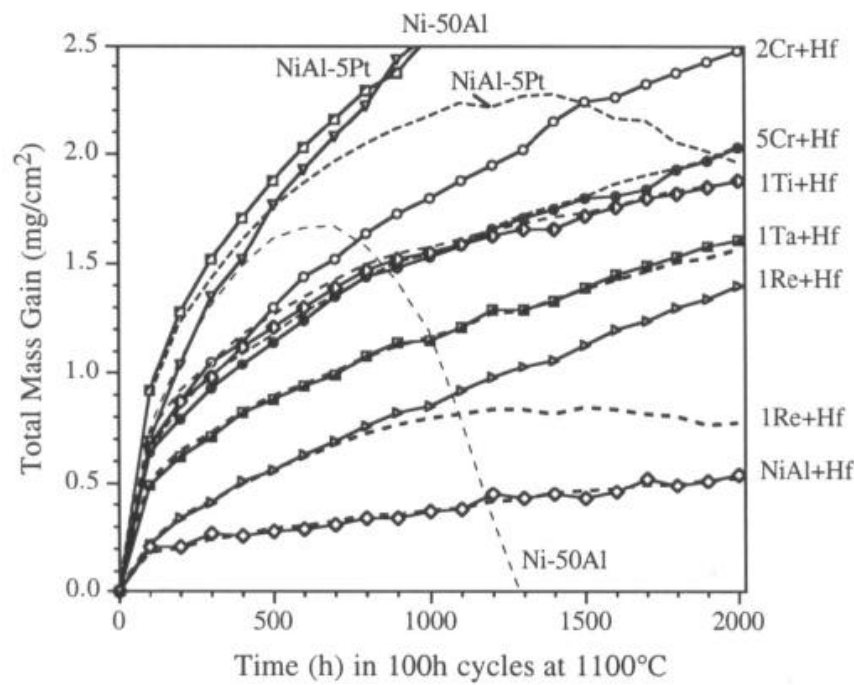

Figure 10. Total mass gain (specimen + spall) for various alloys during $100 \mathrm{~h}$ cycles in alumina crucibles at $1100^{\circ} \mathrm{C}$. Dashed lines show specimen mass changes. Higher total mass gains indicate higher scale growth rates or more scale spallation. 


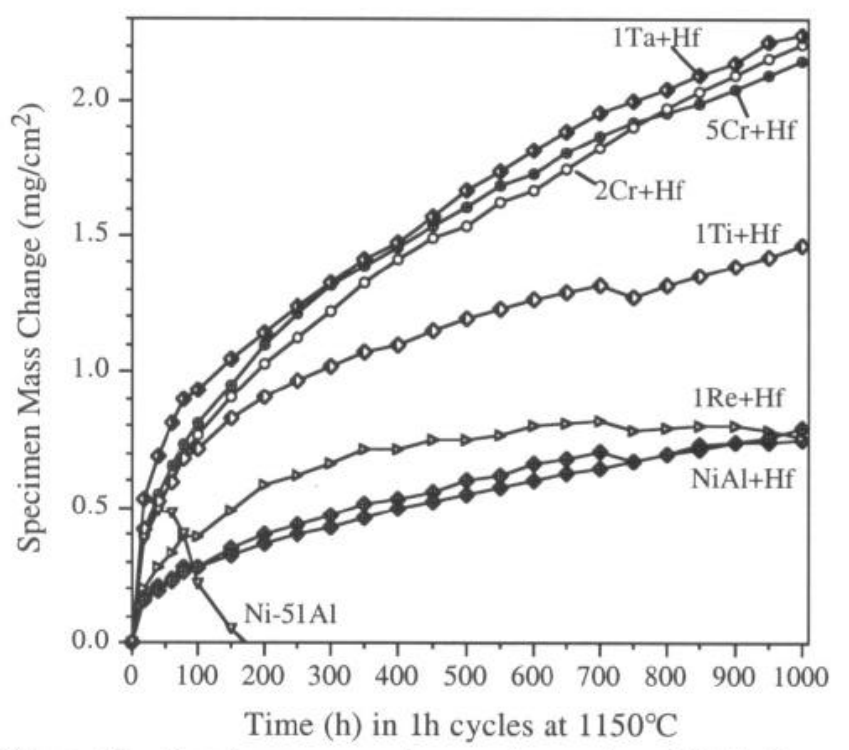

Figure 11. Specimen mass changes for various $\mathrm{Ni}-\mathrm{Al}$ alloys during $\mathrm{lh}$ cycles at $1150^{\circ} \mathrm{C}$ in $\mathrm{O}_{2}$. The addition of $\mathrm{Hf}$ improved scale adhesion and reduced the scale growth rate. When secondary dopants were added, the scale growth rate increased.

\section{Real World Coatings: Co-Doping Effects}

The major problem with the Hf-doping approach is that current aluminide coatings contain numerous other elements besides $\mathrm{Ni}$ and $\mathrm{Al}$ due to interdiffusion with the superalloy substrate.[1] The benefits of $\mathrm{Hf}$ can be compromised if additional elements are also incorporated into the coating. Strong detrimental effects were found from the addition of $1 \% \mathrm{Re}$ and $2-5 \% \mathrm{Cr}$ to $\mathrm{Hf}$-doped $\mathrm{NiAl}$, Figures 10-12. Lesser negative effects were observed for additions of $1 \% \mathrm{Ti}$ or Ta. The data shown in Figure 10 for $1100^{\circ} \mathrm{C}$ are from $100 \mathrm{~h}$ thermal cycles which were used to simulate the longer duty cycles used for land-based gas turbines for power generation. The total mass gain reflects the metal wastage by summing the

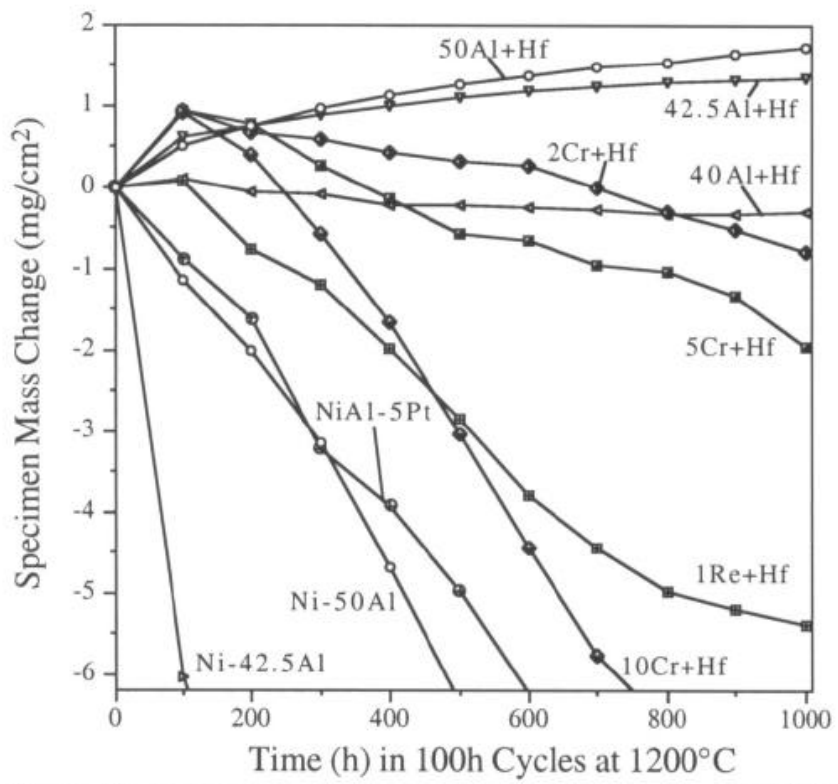

Figure 12. Specimen mass changes during $100 \mathrm{~h}$ cycles at $1200^{\circ} \mathrm{C}$ in air. While $\mathrm{Hf}$ improves $\mathrm{Ni}-\mathrm{Al}$ scale adhesion, additions of $\mathrm{Re}$ and $\mathrm{Cr}$ degrade it. specimen mass gain and spalled scale inside the alumina test crucible. The difference between the total (solid line) and specimen (dashed line) mass gains reflects the amount of scale spallation. The lowest total mass gain was for $\mathrm{NiAl}+\mathrm{Hf}$. Higher mass gains were measured for $\mathrm{NiAl}-1 \mathrm{Re}+\mathrm{Hf}$ due to some scale spallation and for $\mathrm{NiAl}$ with other co-dopants because of an accelerated scale growth rate (and little scale spallation). A similar observation is made for $1 \mathrm{~h}$ cycles at $1150^{\circ} \mathrm{C}$, Figure 11 . Very little scale spallation was observed for $\mathrm{Cr}$ - or $\mathrm{Ta}$-doped $\mathrm{NiAl}+\mathrm{Hf}$ but the scale growth rate was $3-4 \mathrm{X}$ that for $\mathrm{NiAl}+\mathrm{Hf}$. At $1200^{\circ} \mathrm{C}$, the additions of $\mathrm{Cr}$ and $\mathrm{Re}$ were found to cause significant scale spallation during $100 \mathrm{~h}$ cycles, Figure 12 . Thus, the improvements associated with Hf-doping can be compromised to various degrees by other dopants.

After $1000,1 \mathrm{~h}$ cycles at $1150^{\circ} \mathrm{C}$, various co-doped $\mathrm{NiAl}$ specimens were sectioned, Figure 13. As expected from the mass change data, the scale on $\mathrm{NiAl}+\mathrm{Hf}$ was thinnest. The addition of $\mathrm{Ta}, \mathrm{Ti}$ and $\mathrm{Cr}$ resulted in a thicker but adherent scale with an indication of
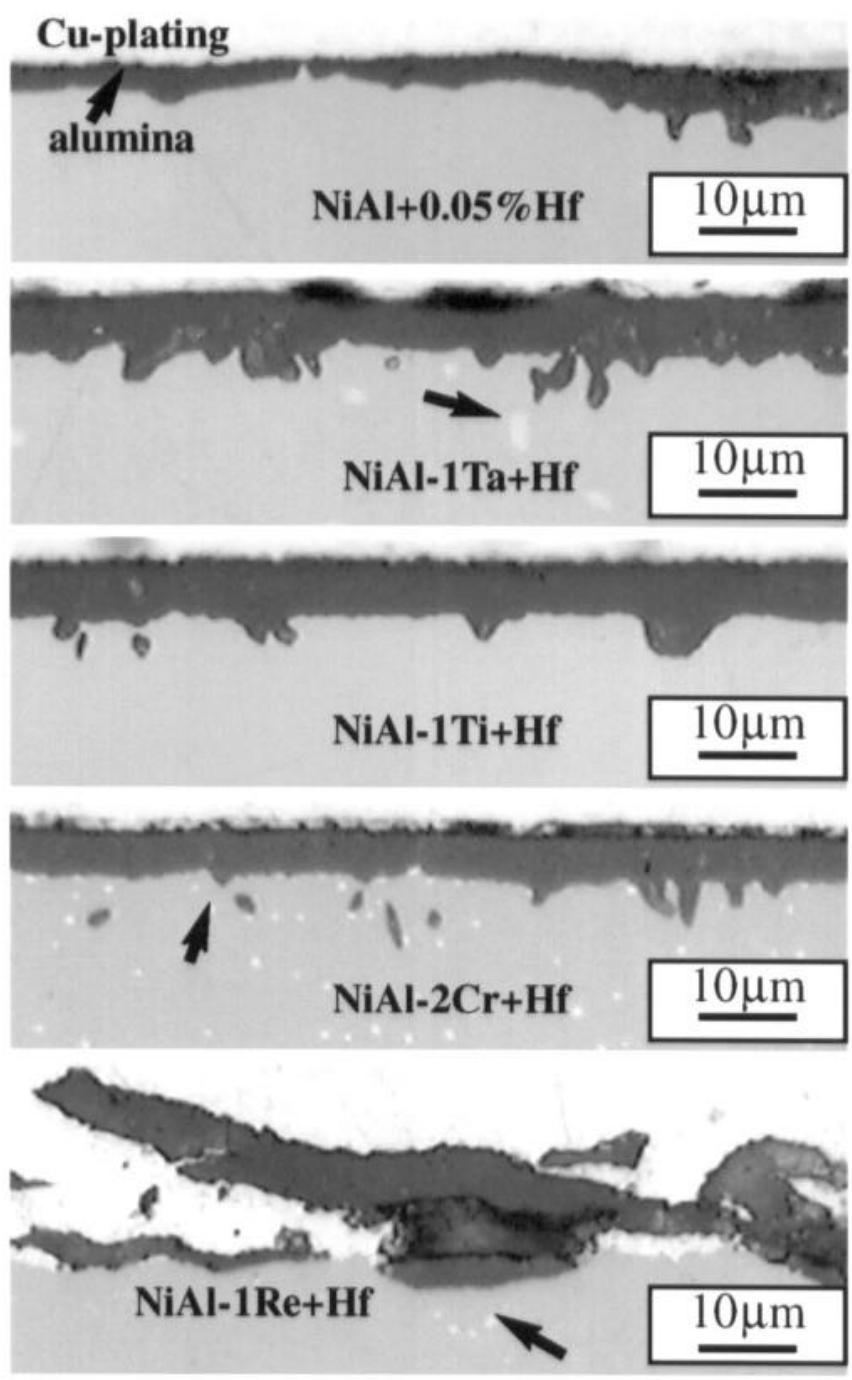

Figure 13. Copper-plated metallographic cross-sections of surface scale after 1000 , 1 h cycles at $1150^{\circ} \mathrm{C}$ on (a) NiAl+Hf; (b) NiAl$1 \mathrm{Ta}+\mathrm{Hf}$, (c) NiAl-1Ti+Hf (d) NiAl-2Cr+Hf and (e) NiAl-1 Re+Hf. The scale on Hf-doped $\mathrm{NiAl}$ was thinner as expected from the mass change data. Precipitates (arrows) are noted with the addition of $\mathrm{Ta}, \mathrm{Re}$ or $\mathrm{Cr}$. 


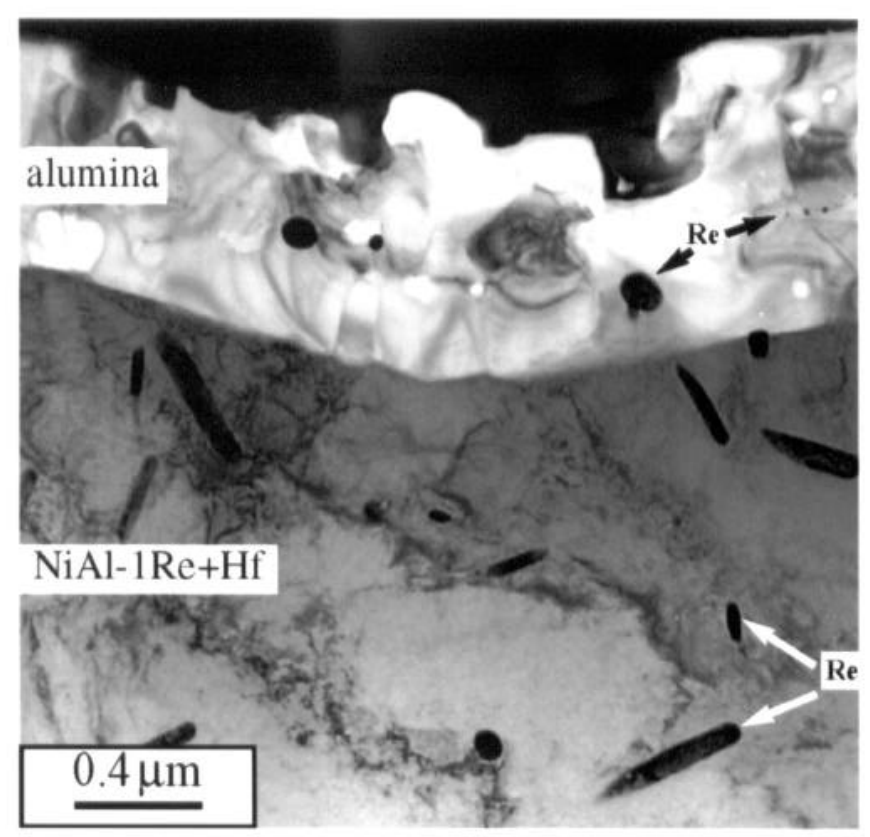

Figure 14. TEM bright field image of the alumina scale formed on $\mathrm{Ni}-50 \mathrm{at} \% \mathrm{Al}-1 \mathrm{Re}-0.05 \mathrm{Hf}$ after $2 \mathrm{~h}$ at $1200^{\circ} \mathrm{C}$ in $\mathrm{O}_{2}$. Re-rich precipitates are observed in the metal and in the oxide.

more oxide penetrations into the substrate in each case, Figures $13 \mathrm{~b}-\mathrm{d}$. Some penetrations contain additional Ta- or Ti-rich oxide particles. The scale on $\mathrm{NiAl}-1 \mathrm{Re}+\mathrm{Hf}$ showed significant scale spallation which also was evident in the mass change data, Figure 11. Additions of $\mathrm{Ta}, \mathrm{Re}$ and $\mathrm{Cr}$ all resulted in precipitate formation in the substrate (arrows in Figures 13b, d \& e).

The same alloys were sectioned for TEM analysis after oxidation for $2 \mathrm{~h}$ at $1200^{\circ} \mathrm{C}$. Compared to the scale on $\mathrm{NiAl}+\mathrm{Hf}$, Figure 9 , the $\mathrm{Ti}$ and $\mathrm{Ta}$ additions showed little effect on the scale microstructure under these conditions. Using STEM/EDX, both $\mathrm{Ta}$ and $\mathrm{Ti}$ ions were found as boundary segregants along with Hf. The Cr- and $\mathrm{Re}$-doped specimens were of more interest as these elements promoted scale spallation at $1200^{\circ} \mathrm{C}$, Figure 12. Both elements formed $\alpha$ precipitates in the $\beta$-matrix which appeared to disrupt scale adhesion. For NiAl-1Re+Hf, $\alpha$-Re particles were observed

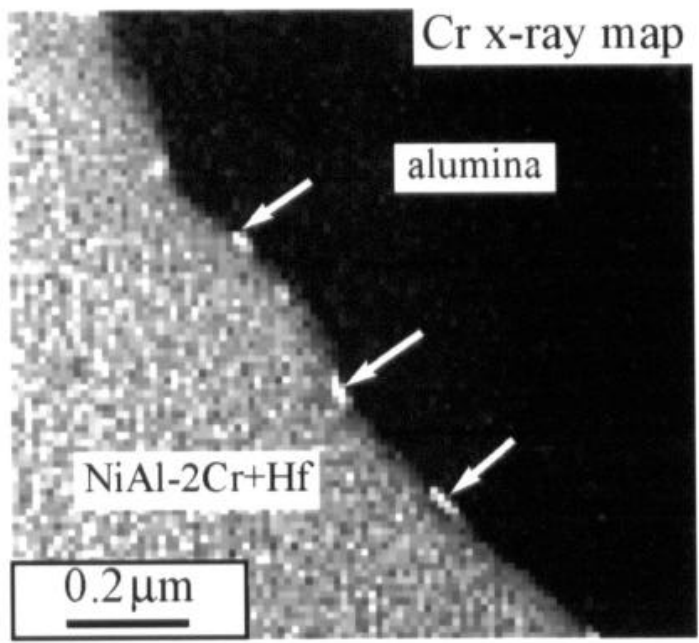

Figure 15. High resolution STEM Cr x-ray map of the scale formed on $\mathrm{Ni}-49 \mathrm{Al}-2 \mathrm{Cr}-0.05 \mathrm{Hf}$ after $2 \mathrm{~h}$ at $1200^{\circ} \mathrm{C}$ in $\mathrm{O}_{2}$. Arrows mark $\alpha$-Cr precipitates at the metal-oxide interface.

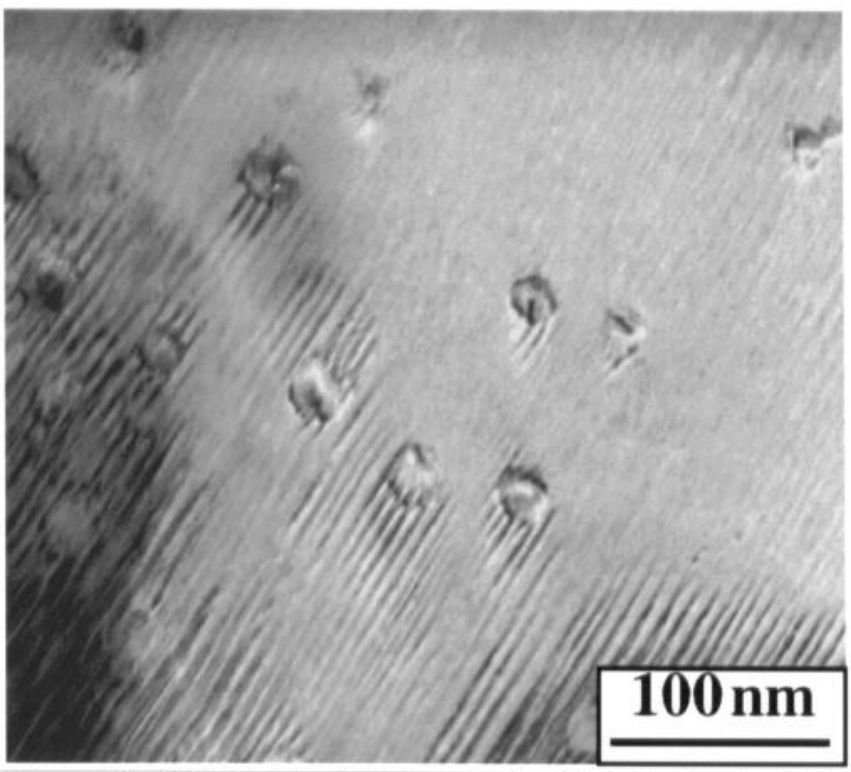

Figure 16. TEM bright field image of a CVD simple aluminide coating on a René N5 substrate after $100 \mathrm{~h}$ at $1150^{\circ} \mathrm{C}$. Cr-rich precipitates are observed throughout the coating.

in the metal and in the oxide, Figure 14, suggesting a low solubility of $\mathrm{Re}$ in the $\beta$ phase. After a $100 \mathrm{~h}$ exposure at $1200^{\circ} \mathrm{C}$, interfacial voids were observed by SEM but, after only $2 \mathrm{~h}$, there was no indication of interfacial void formation in the TEM section. In general, the scale microstructure was very different with coarse ridges and two grains in thickness, much like that on Pt-doped $\mathrm{NiAl}$, Figure 5. The scale formed on $\mathrm{NiAl}-2 \mathrm{Cr}+\mathrm{Hf}$ had a very similar microstructure to that formed on $\mathrm{NiAl}+\mathrm{Hf}$ and $\mathrm{Hf}$ ions were detected as oxide grain boundary and metal-oxide interface segregants. The only difference noted was the presence of small $(30-50 \mathrm{~nm}) \alpha-\mathrm{Cr}$ particles at the metal-scale interface. These particles are shown in the STEM-EDX $\mathrm{Cr}$ X-ray map in Figure 15. Based on metallographic observations of other $\mathrm{Cr}$-doped alloys, these particles appear to increase in size with exposure time and temperature, e.g. Figure 13e. These precipitates are not observed in as-cast NiAl-2Cr+Hf. Their nucleation may be a result of $\mathrm{Cr}$ becoming enriched in the near-surface region as it is rejected from the oxidation front. Since the CTE of $\alpha-\mathrm{Cr}$ is much lower than $\beta,[31]$ the precipitates may cause an additional strain during cooling. Similar Cr-rich $\alpha$ precipitates were also observed in both simple and Pt-modified aluminide coatings, after $100 \mathrm{~h}$ at $1150^{\circ} \mathrm{C}$, Figure 16. Thus a similar mechanism is likely operating in CVD aluminide coatings with these precipitates having a negative effect on scale adhesion.

An additional issue in the development of CVD aluminides is that typically the coatings do not contain $50 \mathrm{at} \% \mathrm{Al}(31.5 \mathrm{wt} \%)$ as did these cast aluminides. A coating will also lose $\mathrm{Al}$ during high temperature exposure by diffusion into the substrate. After only $100 \mathrm{~h}$ at $1150^{\circ} \mathrm{C}, \gamma^{\prime}$ formation was noted by TEM at CVD Ptmodified aluminide grain boundaries, indicating significant $\mathrm{Al}$ loss. [13] $\mathrm{Ni}_{3} \mathrm{Al}$ has significantly worse scale adhesion than $\mathrm{NiAl}$, even when RE-doped.[19,32] This also has been attributed to its higher CTE than NiAl.[22] In order to explore the effect of $\mathrm{Al}$ content within the $\beta$ phase field, $\mathrm{Hf}$-doped $\mathrm{Ni}-\mathrm{Al}$ alloys were cast with $\mathrm{Al}$ contents down to $40 \mathrm{at} \% \mathrm{Al}$, Table I. Doping with $\mathrm{Hf}$ significantly improved the performance of undoped, low Al content $(40-42.5$ at $\%) \mathrm{NiAl}$, Figure 12 . However, the mass loss observed for $\mathrm{Ni}-40 \mathrm{Al}+\mathrm{Hf}$ suggests that it may be more prone to spallation than higher $\mathrm{Al}$ content NiAl. This aspect is still being 
explored with microstructural characterization and lower (35\%) $\mathrm{Al}$ content alloys. Because castings, unlike coatings, do not lose Al by back diffusion, results from castings may not be entirely representative of coating behavior.

\section{$\underline{\text { Discussion }}$}

These results have been compiled in order to suggest some composition guidelines that may lead to bond coats with improved performance. The guidelines relate to oxidation performance and may be altered by mechanical property or other considerations involved in maximizing TBC performance. They are intended as a starting point for an overall discussion of TBC system design and performance.

From an oxidation standpoint, an aluminide coating appears to have greater potential than MCrAlYs for use as a bond coat Though not well recognized, the alumina scale adhesion on NiCrAlY-type alloys is decidedly inferior to that formed on REdoped NiAl or FeCrAlY.[6,7] Cast NiCrAlY spalls readily at $1100^{\circ} \mathrm{C}$ while RE-doped NiAl only spalls after $>1000$ th cycles at $1200^{\circ} \mathrm{C}$. While Pt does improve scale adhesion in aluminides, its potential is limited compared to Hf additions. (One attractive feature of $\mathrm{Pt}$ is that it is easily incorporated into a CVD aluminide coating, unlike Hf.) Many of the beneficial effects often attributed to $\mathrm{Pt}$, such as reducing heavy element diffusion into the coating or increasing the $\mathrm{Al}$ content of the coating, have not been confirmed experimentally. $[2,13]$ One issue that requires further study is the interaction between $\mathrm{Pt}$ and $\mathrm{S}$. Understanding this mechanism may provide useful insight into the role of $S$ in high temperature oxidation. $[33,34]$

The incorporation of Hf into aluminide coatings offers significant improvements in performance and could preclude the use of $\mathrm{Pt}$. The $0.05 \mathrm{Hf}$ level used in this study is sufficient to be uniformly included in the alloy while avoiding excessive internal oxidation associated with higher Hf contents. The best performance would likely be achieved with a coating that only contained $\mathrm{Ni}, \mathrm{Al}$ and $\mathrm{Hf}$. Incorporation of additional elements would inhibit the potential of Hf to improve scale adhesion and, more importantly, to reduce the scale growth rate. The ultimate benefit of proper Hf-doping is the order of magnitude drop in the scale growth rate. The reduction in rate allows longer time at temperature or higher temperature operation before a critical scale thickness is formed where spallation occurs.

The weak point of a pure $\mathrm{NiAl}+\mathrm{Hf}$ coating would be hot corrosion. Chromium was the only element which appeared to improve the hot corrosion resistance of NiAl (Figure 4). However, $\mathrm{Cr}$ increased scale spallation and the isothermal scale growth rate compared to $\mathrm{NiAl}+\mathrm{Hf}$, Figures 10-12. These effects are in good agreement with previously reported work.[35-37] Based on the available data for cast aluminides, it appears that hot corrosion resistance and exceptional scale spallation resistance are mutually incompatible goals for coating performance.

A pure NiAl+Hf coating will be difficult to produce by traditional CVD coating processes. Since elements detrimental to scale growth and adhesion, such as $\mathrm{Cr}$ and $\mathrm{Re}$, incorporate into both inward and outward growing aluminide coatings, the coating essentially must be formed by depositing $\mathrm{Ni}$ as well as $\mathrm{Al}$, with a uniform, low level of $\mathrm{Hf}$ in the coating. This strategy would allow the formation of an initial scale doped solely by $\mathrm{Hf}$ and would require diffusion of substrate elements (e.g. $\mathrm{Ta}, \mathrm{Cr}, \mathrm{Re}$ ) to the gas side of the coating before they could negatively impact oxidation performance. Of course, a stable diffusion barrier between the substrate and coating would further improve this strategy by reducing outward and inward diffusion, but the development of such a barrier appears unlikely.

Attempting to incorporate Hf by surface modifications of the coating is not an appropriate strategy. Ion implantation[38] and $\mathrm{RE}$ surface oxide coatings [39] have been shown to be ineffective alternatives to a uniform $\mathrm{RE}$ distribution in the substrate.[40] $\mathrm{A}$ model for the role of RE dopants on alumina scales suggests that a uniform, constant flux of $\mathrm{RE}$ ions diffusing from the substrate into the oxide scale is necessary to maintain the RE benefit.[25]

A final point is that there appears to be no inherent problem with a thick $(125 \mu \mathrm{m}, 5 \mathrm{mil})$ ceramic coating adhering to a metallic substrate. A $125 \mu \mathrm{m}$-thick, physical vapor deposited, $\mathrm{Y}_{2} \mathrm{O}_{3}$ stabilized $\mathrm{ZrO}_{2}$ coating on $\mathrm{Zr}$-doped $\beta$-NiAl[41,42] had a $20 \%$ coating spallation lifetime of 3600 , th cycles at $1150^{\circ} \mathrm{C}$ and has not reached $20 \%$ spallation after $800,2 \mathrm{~h}$ cycles at $1200^{\circ} \mathrm{C}$. These observations indicate that an extended coating lifetime should result from the formation of an adherent alumina layer. Current bond coats simply do not form alumina scales with sufficient adherence. The next generation of bond coats will require more careful compositional control in order to achieve significant improvements in performance.

\section{Summary}

Based on experimental results from cast aluminides and laboratory-scale CVD aluminide coatings, it appears that singlephase aluminides have a greater potential for the development of improved bond coats than do MCrAlY-based compositions. A series of guidelines is proposed for aluminide coating compositions:

(1) The main features desired in a bond coat to maximize oxidation performance are:

- rapid formation of an $\alpha-\mathrm{Al}_{2} \mathrm{O}_{3}$ scale with no transient oxides

- excellent scale adhesion

- low rate of scale growth

- minimal transport of additional elements into the oxide scale

(2) Pt incorporation provides improved scale adhesion and increases time to first spallation apparently by countering the detrimental role of indigenous sulfur.

(3) Reactive element (Hf) doping of aluminides results in a reduced rate of scale growth

(4) No synergistic benefits are anticipated from co-doping Pt and Hf.

(5) Transport of elements such as $\mathrm{Cr}, \mathrm{Re}, \mathrm{Ti}$ and $\mathrm{Ta}$ to the oxide scale can lead to an increase in oxidation rate and a decrease in resistance to scale spallation.

(6) Within the $\beta$-phase, $\mathrm{Al}$ contents of $50 \mathrm{at} \% \mathrm{Al}$ show better scale adhesion than lower (40at\%) Al contents.

\section{Acknowledgements}

Much of the coatings work is part of the thesis work of Y. Zhang. The authors would like to thank K. M. Cooley, G. Garner, L. D. Chitwood, M. Howell, D. W. Coffey, W. D. Porter and K. S. Trent at ORNL for assistance with the experimental work and P. F. Tortorelli, D. F. Wilson and J. H. DeVan at ORNL for their comments on the manuscript. Work at ORNL was supported by the U.S. Department of Energy (DOE), Assistant Secretary for Energy Efficiency and Renewable Energy, Office of Industrial Technologies, as part of the Advanced Turbine Systems Program under contract DE-AC05-96OR22464 with Lockheed Martin Energy Research. 


\section{$\underline{\text { References }}$}

1. W. Y. Lee, Y. Zhang, I. G. Wright, B. A. Pint and P. K. Liaw, "Effects of Sulfur Impurity on the Scale Adhesion Behavior of a Desulfurized Ni-based Superalloy Aluminized by Chemical Vapor Deposition," Met. Trans. A, 29A (1998), 833.

2. Y. Zhang, W. Y. Lee, J. A. Haynes, I. G. Wright, B. A. Pint, K. M. Cooley and P. K. Liaw, "Synthesis and Cyclic Oxidation Behavior of a (Ni,Pt)Al Coating on a Desulfurized Ni-base Superalloy," Met. Trans. A, 30A (1999), 2679-87.

3. B. A. Pint, P. F. Tortorelli and I. G. Wright, "Effect of Cycle Frequency on High Temperature Oxidation Behavior of Aluminaand Chromia-Forming Alloys," in Cyclic Oxidation of High Temperature Materials, ed. M. Schütze and W. J. Quadakkers (London, UK: The Institutc of Materials, 1999) 111-132.

4. C. Leyens, I. G. Wright and B. A. Pint, "Hot Corrosion of NiBase Alloys in Biomass Derived Fuel Simulated Atmosphere," in Elevated Temperature Coatings: Science and Technology III, ed. J. M. Hampikian and N. B. Dahotre (Warrendale, PA: The Minerals, Metals \& Materials Society, 1999), 79-90.

5. K. L. More, D. W. Coffey, B. A. Pint, K. S. Trent and P. F. Tortorelli, "TEM Specimen Preparation of Oxidized Ni-Based Alloys Using the Focused Ion Beam (FIB) Technique," (Paper presented at Microscopy and Microanalysis 2000, Philadelphia, PA, August 2000).

6. B. A. Pint and I. G. Wright, "Cyclic Oxidation Behavior of cast NiCrAl Alloys," in High Temperature Corrosion and Materials Chemistry, Electrochem. Soc. Proc. v.98-9, ed. P. Y. Hou, M. J. McNallan, R. Oltra, E. J. Opila and D. A. Shores (Pennington, NJ: The Electrochemical Soc., 1998) 263-74.

7. B. A. Pint, K. L. More, I. G. Wright and P. F. Tortorelli, "Characterization of Thermally Cycled Alumina Scales," (Paper presented at Microscopy of Oxidation 4, Cambridge, UK, September 1999).

8. C. E. Lowell, R. G. Garlick and B. Henry, "Thermal Expansion in the $\mathrm{Ni}-\mathrm{Cr}-\mathrm{Al}$ and $\mathrm{Co}-\mathrm{Cr}-\mathrm{Al}$ Systems to $1200^{\circ} \mathrm{C}$ Determined by High-Temperature X-Ray Diffraction," Met. Trans. 7A (1976), 655-60.

9. B. M. Warnes and D.C. Punola, "Clean Diffusion Coatings By Chemical Vapor Deposition," Surf. Coat. 'lechnol., 94-95 (1997), 1-6.

10. B. A. Pint, I. G. Wright, W. Y. Lee, Y. Zhang, K. Prüßner and K. B. Alexander, "Substrate and Bond Coat Compositions: Factors Affecting Alumina Scale Adhesion," Mater. Sci. Eng., 245 (1998), 201-11.

11. H. J. Grabke, D. Weimer and H. Viefhaus, "Segregation of Sulfur During Growth of Oxide Scales," Appl. Surf. Sci. 47 (1991), 243-50.

12. B. A. Pint, "On the Formation of Interfacial and Internal Voids in $\alpha-\mathrm{Al}_{2} \mathrm{O}_{3}$ Scales," Oxid. Met., 48 (1997), 303-28.

13. A. Haynes, Y Zhang, W. Lee, B. Pint, I. Wright and K. M. Coolcy, (1999) "Effects of Pt Additions and S Impurities on the Microstructure and Scale Adhesion Behavior of Single-Phase CVD Aluminide Bond Coatings," in Elevated Temperature Coatings: Science and Technology III, ed. J. M. Hampikian and N. B. Dahotre (Warrendale, PA: The Minerals, Metals \& Materials Socicty, 1999), 79-90.

14. C. Leyens, B. A. Pint and I. G.Wright, "Effects of Composition on the Hot Corrosion Resistance of $\mathrm{NiAl}$ and (Ni,Pt)Al," NACE Paper 00-260, Houston, TX, presented at NACE Corrosion 2000, Orlando, FL, March 2000.

15. E. J. Felten and F. S. Pettit, "Development, Growth, and Adhesion of $\mathrm{Al}_{2} \mathrm{O}_{3}$ on Platinum-Aluminum Alloys," Oxid. Met, 10 (1976), 189-223.

16. H. M. Hindam and W. W. Smeltzer, "Growth and Microstructure of $\alpha-\mathrm{Al}_{2} \mathrm{O}_{3}$ on $\beta-\mathrm{NiAl}$," J. Electrochem. Soc., 127
(1980), 1630-5.

17. B. A. Pint, J. R. Martin and L. W. Hobbs, " $18 \mathrm{O} / \mathrm{SIMS}$ Characterization of the Growth Mechanism of Doped and Undoped $\alpha-\mathrm{Al}_{2} \mathrm{O}_{3}$," Oxid. Met. 39 (1993), 167-95.

18. B. A. Pint, M. Treska and L. W. Hobbs, "The Effect of Various Oxide Dispersions on the Phase Composition and Morphology of $\mathrm{Al}_{2} \mathrm{O}_{3}$ Scales Grown on $\beta-N i A l$," Oxid. Met., 47 (1997), 1-20.

19. J. D. Kuenzly and D. L. Douglass, "The Oxidation Mechanism of $\mathrm{Ni}_{3} \mathrm{Al}$ Containing Yttrium," Oxid. Met., 8 (1974), 139-178.

20. B. A. Pint, "The Oxidation Behavior of Oxide-Dispersed $\beta$ NiAl: I. Short-Term Cyclic Data and Scale Morphology," Oxid. Met., 49 (1998), 531-60.

21. J. T. DeMasi-Marcin, K. D. Sheffler and S. Bose, "Mechanisms of Degradation and Failure in a Plasma-Deposited Thermal Barrier Coating," J. Eng. Gas Turb. \& Power, 112 (1990), $522-7$.

22. J. Doychak, "Oxidation Behavior of High Temperature Intermetallics," in Intermetallic Compounds, Vol.1: Principles, ed. J. H. Westbrook and R. L. Fleischer (New York, NY: John Wiley \& Sons, 1994) 977-1016.

23. B. A. Pint, A. J. Garratt-Reed and L. W. Hobbs, "The Reactive Element Effect in Commercial ODS FeCrAl Alloys," Mater. High Temp., 13 (1995), 3-16.

24. E. Schumann, J. C. Yang, M. Rühle and M. J. Graham, "High Resolution SIMS and Analytical TEM Evaluation of Alumina Scales on $\beta$-NiAl Containing Zr or Y," Oxid. Met., 46 (1996), 3749 .

25. B. A. Pint, "Experimental Observations in Support of the Dynamic Segregation Theory to Explain the Reactive Element Effect," Oxid. Met., 45 (1996), 1-37.

26. C. Mennicke, E. Schumann, C. Ulrich and M. Rühle, "The Effect of Yttrium and Sulfur on the Oxidation of FeCrAl," Mater. Sci. Forum, 251-4 (1997), 389-96.

27. B. A. Pint and K. B. Alexander, "Grain Boundary Scgregation of Cation Dopants in $\alpha-\mathrm{Al}_{2} \mathrm{O}_{3}$ Scales," J. Electrochem. Soc., 145 (1998), 1819-29.

28. B. A. Pint, A. J. Garratt-Reed and L. W. Hobbs, "Possible Role of the Oxygen Potential Gradient in Enhancing the Diffusion of Foreign Ions on $\alpha-\mathrm{Al}_{2} \mathrm{O}_{3}$ Grain Boundaries," J. Amer. Ceram. Soc. 81 (1998), 305-14.

29. E. C. Dickey, B. A. Pint, K. B. Alexander and I. G. Wright, "Oxidation Behavior of Platinum-Aluminum Alloys and the Effect of Zr-Doping," J. Mater. Res., 14 (1999), 4531.

30. K. Y. Kim, S. H. Kim, K. W. Kwon and I. H. Kim, "Effect of Yttrium on the Stability of Aluminide-Yttrium Composite Coatings in a Cyclic High-Temperature Hot-Corrosion Environment," Oxid. Met., 41 (1994), 179-201.

31. K. Fritscher, C. Leyens and M. Peters, "Development of a Low-Expansion Bond Coating for Ni-base Superalloys," Mater. Sci. Eng., A190 (1995), 253-8.

32. B. A. Pint, A. J. Garratt-Reed and I. W. Hobbs, "Analytical Electron Microscopy Study of the Breakdown of $\alpha-\mathrm{Al}_{2} \mathrm{O}_{3}$ Scales Formed on Oxide Dispersion Strengthened Alloys," submitted to Met. Trans. A.

33. J. G. Smeggil, A. W. Funkenbusch and N. S. Bornstein, "A Relationship Between Indigenous Impurity Elements and Protective Oxide Scale Adherence Characteristics," Met. Trans., 17A (1986), 923-32.

34. J. L. Smialek, D. T. Jayne, J. C. Schaeffer and W. H. Murphy, "Effects of Hydrogen Annealing, Sulfur Segregation and Diffusion on the Cyclic Oxidation Resistance of Superalloys: A Review," Thin Solid Films, 253 (1994), 285-92.

35. R. A. Rapp, "Chemistry and Electrochemistry of Hot Corrosion of Metals," Mater. Sci. Eng. 87 (1987), 319-27.

36. J. G. Smeggil, "The Effect of Chromium on the High 
Temperature Oxidation Resistance of Ni:Al," Surf. Coat. Tech., 46 (1991), 143-53.

37. D. L. Ellis, "Hot Corrosion of the B2 Nickel Aluminides," (Report CR 191082, NASA Lewis Research Center, Cleveland, $\mathrm{OH}, 1993)$.

38. G. Fisher, P. K. Datta, J. S. Burnell-Gray, W. Y. Chan and J. C. Soares, "The Effect of Active Element Additions on the Oxidation Performance of a Platinum Aluminide Coating at $1100^{\circ} \mathrm{C}$," Surf. Coat. Tcch., 110 (1998), 24-30.

39. P. Y. Hou, Z. R. Shui, G. Y. Chuang and J. Stringer, "Effect of Reactive Element Oxide Coatings on the High Temperature Oxidation Behavior of a FeCrAl Alloy," J. Electrochem. Soc., 139 (1992), 1119-26.

40. B. A. Pint, "Limitations on the Use of Surface Doping for Improving High-Temperature Oxidation Resistance," Mater. Res. Soc. Bull., 19 (10) (1994), 26-30.

41. B. A. Pint, B. A. Nagaraj, and M. A. Rosenzweig, "Evaluation of TBC-Coated $\beta$-NiAl Substrates Without a Bond Coat," in Elevated Temperature Coatings: Science and Technology II, ed. N. B. Dahorte, J. M. Hampikian, and J. J. Stiglich (Warrendale, PA: The Minerals, Metals \& Materials Society, 1996), 163-74.

42. B. A. Pint, I. G. Wright and W. J. Brindley, "Evaluation of TBC Systems on Novel Substrates," J. Thermal Spray Technol., in press (2000). 